\title{
Transcendence, Taxis, Trust: Richard Kearney and Jacques Derrida
}

\author{
Ulrich Schmiedel
}

Evangelisch-Theologische Fakultät, Ludwig-Maximilians-Universität München, Geschwister-Scholl-Platz 1, 80539 Munich, Germany; ulrich.schmiedel@lmu.de

Academic Editor: Justin Sands

Received: 18 January 2017; Accepted: 6 March 2017; Published: 9 March 2017

\begin{abstract}
Whatever else it takes to drive a taxi, it takes trust. Day after day, the driver has to decide whether the other is or is not trustworthy. I take the taxi as a test case to analyze and assess Richard Kearney's diacritical hermeneutics of the other. I argue that Kearney functionalizes the concept of transcendence in order to connect the transcendence of the finite other to the transcendence of the infinite other. However, in his central critique of the deconstructionists following Jacques Derrida, Kearney counters his connection. While Kearney's critique of Derrida's account of absolute alterity is correct and compelling, I argue that Derrida's critique of a distinction between the trustworthy other and the non-trustworthy other might be more crucial than Kearney contends. Insisting on openness to the other's otherness, Derrida provokes any hermeneutic of the other to trust in transcendence. The taxi is taken as a test to illustrate the implications which diacritical and deconstructive drivers might have for evaluating the entanglement of ethics and eschatology-inside and outside the taxi.
\end{abstract}

Keywords: transcendence; immanence; trust; Richard Kearney; Jacques Derrida; alterity; otherness

Whatever else it takes to drive a taxi, it takes trust. ${ }^{1}$ Day after day, the driver is confronted with a crucial decision. Is my potential passenger trustworthy? Is my potential passenger not trustworthy? And how do I tell the difference? The decision has to be made before the driver can collect knowledge about her potential passenger. Once the passenger takes a seat in the taxi, it is too late-she might disappoint the trust of the driver, a disappointment which could have precarious and perilous consequences.

Arguably, the driver's decision amounts to the wager which is at the core of Richard Kearney's trilogy, "Philosophy at the Limit". ${ }^{2}$ By "wager," Kearney (playing with the weightiest wagerer in the history of Christianity, Blaise Pascal ${ }^{3}$ ) means an existential, rather than an epistemological, decision about the other. ${ }^{4}$ Of course, Kearney's wager exceeds the economic exchange between the one who drives and the one who is driven in the taxi. However, in order to make a decision about the other, the driver, nonetheless, needs a hermeneutic, a "diacritical hermeneutic" which allows the self to relate to the other and the other to relate to the self [3]. The taxi, then, is a case which illustrates what happens when one encounters the other. Kearney's hermeneutic-sharpened in the follow-up to his trilogy, Anatheism: Returning to God after God [7] - makes the taxi ride much more tantalizing: Kearney argues that the exposure to any finite other might entail the appearance of the infinite other as much as the exposure to the infinite other might entail the appearance of any finite other ([1], pp. 9-19). God might

1 I am grateful to all the students who participated in my seminar on "Religion and Critiques of Religion" at Ludwig-Maximilians-Universität München in 2016/17. The questions and quandaries we discussed there made their way into this article-sometimes more explicitly and sometimes more implicitly.

2 The trilogy consists of [1-3].

3 See [4]. For Kearney's account, see [5].

4 [6], concludes that Kearney's wager is "quasi-confessional." 
take a seat in the taxi. What is at stake in the taxi is the entanglement of ethics and eschatology. ${ }^{5}$ For Kearney, both have to do with the other-ethics with the present other and eschatology with the potential other. When the driver has to decide about the other whom she does not know, the present ethical other is also a potential eschatological other and the potential eschatological other is also a present ethical other. Driving a taxi is about trust as much as it is about transcendence.

In what follows, I will analyze Kearney's hermeneutic of the other, assessing how he approaches alterity - the otherness of the other-though the conceptual couple of 'immanence' and 'transcendence.' I will argue that Kearney functionalizes transcendence. The functionalization is what allows him to connect the transcendence of the finite other to the transcendence of the infinite other through their otherness. However, in his central critique of the deconstructionists following Jacques Derrida, Kearney counters his connection between the finite and the infinite through otherness. While Kearney's critique of Derrida's account of absolute alterity is correct and compelling, I argue that Derrida's critique of a distinction between the trustworthy other and the non-trustworthy other might be more crucial than Kearney contends. Taking philosophical-phenomenological descriptions of trust as a point of departure, ${ }^{6}$ I will account for Kearney as a corrective to Derrida and for Derrida as a corrective to Kearney. Derrida, "the last eschatologist," is more important and more instructive to think through the entanglements of ethics and eschatology than Kearney implies. Insisting on openness to the other's otherness, Derrida provokes any hermeneutic of the other to trust in transcendence. The taxi is taken as a test that illustrates the implications which diacritical and deconstructive drivers might have for the entanglement of ethics and eschatology—inside and outside the taxi.

\section{The Diacritical Taxi Driver}

Kearney elaborates on a hermeneutic which explores the other through the conceptual couple of 'transcendence' and 'immanence.' This hermeneutic, Kearney explains, is neither "romantic" nor "radical," but "diacritical" ([3], p. 17). While romantic hermeneutics offer modern accounts of interpretation which aim at convergence between the interpreter and the interpreted, radical hermeneutics offer postmodern accounts of interpretation which aim at divergence between the interpreter and the interpreted ([3], pp. 3-20). Both the romantic and the radical hermeneutics map onto the interpretation of the other. If the interpreter and the interpreted converge too much, the other becomes so familiar that the relation to her collapses into interiority. If the interpreter and the interpreted diverge too much, the other becomes so foreign that the relation to her collapses into exteriority. In order to counter this collapse, ${ }^{8}$ Kearney proposes "to make the foreign more familiar and the familiar more foreign" ([3], p. 11). His diacritical hermeneutic, then, is about a relation between the interpreter and the interpreted, a relation to the other. But who, or what, is the other?

Kearney answers not by explaining who or what the other is, but by explaining who or what the other is not. In accordance with his hermeneutic, he introduces the conceptual couple of 'immanence' and 'transcendence': "if others become too transcendent" and "if others become too immanent," he argues, "they become equally exempt from ethical relation" [3]. The consequence of this exemption is that one cannot distinguish between the other who should be welcomed and the other who should not

5 Of course, Kearney is inspired by Emmanuel Levinas, especially Levinas's account of ethics. See [8]. Although it would be exciting to explore the immense impact of Levinas, it is not essential to my argument about Kearney's critique of Derrida (and Derrida's critique of Kearney). Accordingly, I can only offer pointers to Levinas where his oeuvre is of special significance for my discussion.

6 Both philosophically and theologically, the discussion of Kearney's disagreement with Derrida (and Derrida's disagreement with Kearney) has been depicted as a disagreement about the notoriously nebulous notion of "khora." See esp. ([3], pp. 191-212). Turning to phenomenology, I will introduce theories of trust into the depiction of the disagreement in order to tease out where the two philosophers can learn from each other.

7 ([9], p. 67); with reference to ([10], p. 155).

8 Arguably, the history of hermeneutics-both in its romantic and in its radical manifestations-is more subtle and more sophisticated than Kearney's account suggests. However, he points to the extreme cases on both sides of the hermeneutical spectrum. 
be welcomed ([3], pp. 9-10). Ethics, which, according to Kearney, is centrally concerned with this distinction, evaporates. ${ }^{9}$ Countering the evaporation of ethics, Kearney, the "master of the middle way," 10 constructs a "double critique" within his diacritical hermeneutic: like the radicals (but unlike the romantics), he criticizes the extreme of interiority in the account of the other; like the romantics (but unlike the radicals), he criticizes the extreme of exteriority in the account of the other ([3], p. 10). "This double critique requires a delicate balance" ([3], p. 11), because it "suggests that the other is neither absolutely transcendent nor absolutely immanent, but somewhere between the two" ([3], p. 79). That the other is "somewhere between" immanence and transcendence is crucial: it implies that the concepts of immanence and transcendence are not approached as static substances. Instead, in the encounter with the other, Kearney insists, immanence is connected to transcendence and transcendence is connected to immanence. The other is both immanent and transcendent.

Kearney turns to theology (notwithstanding the difference between philosophy and theology ${ }^{11}$ ) in order to identify the significance of immanence and transcendence for the interpretation of the other-the creature as well as the creator. The concepts "person" and "persona" are central to Kearney's theological turn. ${ }^{12}$ He distinguishes between the other's person and the other's persona: "person" means the immanence of the other which can be identified; "persona" means the transcendence of the other which cannot be identified ([1], p. 10). Persona, then, points to "the otherness of the other" which is encountered in each and every person. ${ }^{13}$ Here, the finite other and the infinite other meet ([1], p. 2). Yet the otherness of the other is not a site where the finite other is infinite or where the infinite other is finite. Instead, the finite and the infinite other are connected through their otherness. Kearney contends that otherness-the otherness of the finite other or the otherness of the infinite other-cannot be curtailed or controlled ([1], pp. 10-12). Experientially, the otherness of the other transcends the concepts one constructs about the other because each and every other escapes one's evaluations and exceeds one's expectations. The other is otherwise, confronting the one who encounters her with a "surplus of meaning" which cannot be completely captured ([1], p. 47).

Accordingly, Kearney advocates for what I would call a functionalization of transcendence. ${ }^{14}$ Although functionalization is a technical term taken from sociology of religion, rather than philosophy of religion, it concisely captures Kearney's post-metaphysical concept of transcendence: transcendence is interpreted according to what it does-to transcend. ${ }^{15}$ If one opts for a substantial in contrast to a functional conceptualization, immanence cannot spill into transcendence and transcendence cannot spill into immanence. When Karl Barth argues that the creator touches the creation through revelation "as a tangent touches a circle, that is, without touching it," he seems to opt for such a substantial definition. ${ }^{16}$ In contrast to Barth, Kearney's account of transcendence interprets the experience of transcendence as otherness and the experience of otherness as transcendence-as a surplus which cannot be captured completely or conclusively. Insofar as she "transcends" what Kearney calls "our possession, our prejudice," the other "appears as the transcendent other" ([22], p. 79). The functionalization of transcendence, then, is what allows Kearney to argue that the exposure to any finite other enables the appearance of the infinite other (as much as the exposure to the infinite other

9 Ethics is central to Kearney's diacritical hermeneutics which emphasizes the significance of practice. See ([2], pp. 3-14, 125-26). For the emphasis on ethics, see also ([11], p. 107; [12], p. 731; [13], p. 254).

10 Mark Dooley [14], argues that Kearney's mediation between the extremes brings him close to Georg W. F. Hegel, although "he eschews Hegel's teleological absolutism." ([14], p. 330).

11 See [15]. See also Boeve ([6], p. 310), who-in contrast to Sands-argues that Kearney's "poetics of the possible God seem to mix up philosophy and theology."

12 For Kearney's theological turn, see ([16], pp. 253-54).

13 [1]. The otherness of the other provokes the narratives which allow for interpretations of the other which remain open to the other's otherness. See ([2], pp. 125-56). See also ([17], pp. 106-7).

14 I borrow the distinction between functional and substantial approaches to definitions from the controversial conversations about the concept of religion in sociology: the functional approach focuses on what religion does, while the substantial approach focuses on what religion declares. For a short summary, see [18].

15 For a metaphysical critique of Kearney, see [19].

16 ([20], p. 30). See also Ingolf U. Dalferth ([21], pp. 146-88), who re-works Barth's definition philosophically. 
enables the appearance of any finite other). The otherness of the other is interpreted as the "trace" of God ([1], p. 18). So, who or what is the other? For Kearney, the other is a sacrament. ${ }^{17}$ When, in theological terminology, the creator can be encountered "in" the otherness of the creature and the creature can be encountered "in" the otherness of the creator ([1], p. 18), then the otherness of the other is a sacramental site.

In Anatheism, Kearney argues that religion originates in the otherness of the other. He stresses sacramental sites and sacramental scenes in the Abrahamic religions where the encounter with the other is shaped by a tension between the transcendence of the other and the immanence of the other ([7], pp. 17-20). "Out of this tension faith leaps" ([7], p. 15). Kearney points to Rudolf Otto's phenomenology of The Holy to portray the origin of religion(s) as ambiguous: the otherness of the other triggers fascination as much as it triggers fear ([7], p. 38; [23]). In order to account for this ambiguity, he returns to hermeneutics. Reminiscent of his teacher Paul Ricoeur, Kearney argues that his diacritical hermeneutic connects one's ability to express the otherness of the other and one's inability to express the otherness of the other through metaphors. ${ }^{18}$ When one encounters the other, one simultaneously can and cannot express who she is. Due to this simultaneity, the otherness of the other is both present and not present to the one who encounters the other: present in its absence, absent in its presence. The otherness of the other is present "as if" ([1], p. 10).

The simultaneity of expression and inexpression - the "provisio" of the other-is essential to Kearney's entanglement of (his hermeneutical) ethics and (his hermeneutical) eschatology [1]. Since the other exceeds the evaluations and the expectations one might have of her, one can control neither what she can be nor what she can become. The "end" of the other is "an end that escapes."19 Because she escapes one's control, the relation to the other requires the "ek-stasis of the self" ([1], p. 16). Kearney explains the ex-stasis of the self through repeated references to the concept of trust ([7], pp. 3, 22, 30, 36, 44, 144, 203). Although he offers neither a definition nor a discussion of trust, ${ }^{20}$ his references convey the core characteristic of the concept: the self is "surpassing itself toward the other who surpasses it" so that it opens itself up to the otherness of the other-ethically to the present other and eschatologically to the potential other. ${ }^{21}$ In the encounter with the other who transcends one's evaluations and one's expectations, then, ethics and eschatology coincide. Kearney refers to "ethical time," a time which is not chromatic but chiromatic, to reflect on the moment in which one is encountered by the other. ${ }^{22}$ It is the messianic moment in which one is open(ed) to the incoming other that allows for the realization of eschatology. ${ }^{23}$

According to Kearney, the otherness of the other is the reason for the emphasis on ethics and eschatology in the Abrahamic religions. The amalgamation of expressibility and inexpressibility in alterity runs "down through the entire 'effective-history' (Wirkungsgeschichte) of Christian theology" ([1], p. 47). Throughout the effective history of theology, both ethics and eschatology are reliant on a relation to the other ([1], p. 18). However, because the relation is not innocent, one

17 Throughout his trilogy, Kearney theorizes what I would call a sacramental account of the other. However, the terminology of sacramentality is articulated and applied only in Anatheism, where Kearney explains that "[s]acramental return is a retrieval of the extraordinary in the ordinary" ([1], p. 86). Although sacramentality is not restricted to Christianity, Jesus is crucial for Kearney's account. See ([1], p. 40).

18 See esp. [24]. For Kearney's account, see [25].

19 ([1], p. 12). Kearney insists that the end without end of eschatology inhibits any teleology. The "u-topian no-place of persona," he argues, "brings home to us that we have no power over her/him" [1].

20 ([7], p. 3). Kearney portrays the encounter with the immanent-transcendent other as follows: "what happens in the decisive instant when the sacred stranger appears: do we respond with hostility or hospitality?" Here, Kearney introduces "trust" as a crucial component of the hospitable in contrast to the hostile response [7].

21 ([1], p. 16). Throughout, Kearney applies openness to the concept of God, advocating for "possibility" as a mode of God. Accordingly, he accounts for the "God of Exodus 3 neither as 'I who am' nor as 'I who am not' but rather as 'I am who may be'-that is, as the possibility to be, which obviates the extremes of being and non-being" ([1], p. 22). See also [26]. For a succinct summary, see [27].

22 See ([1], pp. 16-17). For Kearney's notion of eschatology, see also [28].

23 See ([7], p. 29). See also ([29], pp. 53-54), where he covers Levinas's concept of achronicity, which "transcends all chronologies of time" ([29], p. 53). 
needs to draw a distinction between the other who should be welcomed and the other who should not be welcomed, between the "benign" and the "malign" other ([3], p. 67). This distinction is staged in the Bible where Kearney sees "a story of struggles between different ways of responding to the alien" ([7], p. 20). In these stories, "two responses are registered: hostility or hospitality" ([7], p. 17). However, within the stark and striking contrast between hostility and hospitality which Kearney introduces, he opts neither for hospitality instead of hostility, nor for hostility instead of hospitality; on the contrary, he argues that a decision about whether the other should or should not be welcomed depends on the other. Trust is a crucial component of the hospitable response. ${ }^{24}$ Yet to draw the distinction between trustworthy and non-trustworthy others, a diacritical hermeneutic is neededa hermeneutic which allows the hermeneut to think about the other without confining the other to her thoughts ([1], pp. 48-49).

To summarize, Kearney interprets 'the other' through 'transcendence' and 'transcendence' through 'the other.' This functionalization of transcendence allows him to advocate for the other as a sacramental site where finite creature and infinite creator meet. Both are characterized by their otherness, both transcend one's evaluations and one's expectations. Hence, for Kearney, the driver's decision about whether she should or should not take the other into her taxi is delicate: in the transcendence of the other, the driver could encounter a monster as well as a messiah. Kearney criticizes the romantic hermeneutic and the radical hermeneutic because, in these hermeneutics, the distinction between the other who should be welcomed and the other who should not be welcomed cannot be drawn. Since the other either converges into interiority or diverges into exteriority, the self cannot interpret the other. The consequence is "undecidability." ${ }^{25}$ There is no way of telling whether the other is or is not sacramental, whether she is malign or benign. Trust is blind ([1], p. 67). Although Kearney's critique of "undecidability" concerns both the romantics and the radicals, he concentrates on the deconstructionists who follow Jacques Derrida.

\section{The Deconstructive Taxi Driver}

"Undecidability" is at the core of Jacques Derrida's conceptualization(s) of hospitality. In the encounter with the other, Derrida argues, both hospitality and hostility are viable options. He accounts for the viability of these options through the etymologies of "hospitality" and "hostility" which converge in one concept, the Latin hostis. ${ }^{26}$ According to Derrida, the convergence of hospitality and hostility is at work in every encounter with the other- "hostipitality." Concentrating on its "troubled and troubling origin" ([31], p. 3). Derrida contends that "[w]e do not know what hospitality is. Not yet" ([31], p. 6). On the contrary, hospitality is a concept which deconstructs itself ([31], p. 5). The "deconstruction" or "self-deconstruction" of hospitality is Derrida's central concern [31].

In "Hostipitality," Derrida interprets hospitality as a way of welcoming the other. Since the other is otherwise, hospitality "proceeds beyond knowledge toward the other" ([31], p. 8). Here, he comes close to Kearney's implicit interpretation of trust as the ek-statis of the self. However, for Derrida, the center of trust is not to know the other, but to not know the other-which means that one welcomes her regardless of whether she does or does not deserve to be welcomed, unconditionally rather than conditionally. ${ }^{27}$ Hospitality, then, involves a reversal of roles between the one who welcomes and the

24 See ([7], p. 22), where Kearney insists that hospitality is not a given. It requires trust.

25 ([3], p. 9). "Undecidability" is one of the core concepts of deconstruction. John D. Caputo [30], however, argues that Kearney misinterpreted what the deconstructive "devil of undecidability" ([30], p. 88), is about: "He has confused undecidability with indecision, instead of recognizing that undecidability is not indecision but the condition of possibility of a decision. The opposite of undecidability is not a decision or decisiveness but rather "programmability" ([30], p. 90).

26 See ([31], p. 3). See also [32]. For the etymology of hospitality/hostility, Derrida refers to [33].

27 Gerasimos Kakoloris [34] arrives at the same conclusion as Kearney. However, he is puzzled that Derrida, the critic of binaries, concurs with the binary of impure conditional hospitality and pure unconditional hospitality. While he accepts that, for Derrida, both concepts of hospitality condition and crisscross each other, he is critical of Derrida's conclusion that "this asymmetry between conditional and unconditional hospitality maintains an endless demand, since each event of welcoming the other can only fall short" ([34], p. 149), because it renders ethical responsibility impossible. 
one who is welcomed: when the master of the house makes no demands, the guest becomes the master and the master becomes the guest. ${ }^{28}$ However, in this reversal of roles, Derrida insists, hospitality implodes: on the one hand, the master should be the master in order to welcome (which means she should stipulate conditions because otherwise there would be no home to which the other could be welcomed); on the other hand, the master should not be the master in order to welcome (which means she should not stipulate conditions because otherwise there would be no other who could be welcomed to the home). Accordingly, hospitality is held in a "double bind" ([31], p. 12). This double bind makes hospitality possible and impossible at once; without it, "hospitality...would have no chance of coming to pass" ([32], p. 13). The "deconstruction" or "self-deconstruction" of hospitality which Derrida describes originates in the otherness of the other. ${ }^{29}$

Kearney agrees with Derrida (and Derrida with Kearney) that the otherness of the other inaugurates religion(s) ([35], pp. 40-101). It is the interpretation of otherness, however, in which they differ. For Derrida, the other has to be conceived of as "absolute" ([31], p. 8): she, he or it cannot be named ([32], p. 25). "If there is a horizon," Derrida insists, "it is not what phenomenologists call the horizon of expectation, since it could be anyone" ([31], p. 10). The one who welcomes "waits without waiting. He waits without knowing whom he awaits" [31]. Hence, although hospitality has a history, "the experience of hospitality hold[s] a future beyond this history" [31]: "What we call hospitality maintains an essential relation with the opening of what is called to come [à venir]. When we say that 'We do not yet know what hospitality is,' we also imply that we do not yet know who or what will come" ([31], p. 11). Hence, it "is necessary to do the impossible. If there is hospitality, the impossible must be done" ([31], p. 14). The one who welcomes any other as the absolute other and the absolute other as any other "waits for the Messiah. He waits for anyone whom might come" ([31], p. 11). Elsewhere, Derrida explains his eschatology by exploring prayer:

[S]uspension must take place in order for prayer to be authentic. If I...were simply expecting an answer, that would be the end of prayer. That would be an order-just as though I were ordering a pizza! (Laughter). No, I expect nothing like that. I assume that I must give up any expectation, any certainty, as the one, or the more than one, to whom I address my prayer, if this is still a prayer ([36], p. 31).

For Derrida, then, eschatology explodes any ethics which works with the distinction between the other who should be welcomed and the other who should not be welcomed..$^{30}$ Ethics would have to be open(ed) to any other as the absolute other.

Kearney disagrees with Derrida's account of alterity as absolute. ${ }^{31}$ Where "Derrida confronts us with the utterly unidentifiable character of alterity, beyond all horizons of human or historical anticipation" ([8], p. 107), there is no distinction between the other as a monster and the other as a messiah. ${ }^{32}$ According to Kearney, Derrida's lack of distinction has crucial consequences for religion. Theologically, Derrida "calls for a 'religion beyond religion'" in which one cannot "give a name to God at all." 33 Derrida rightly passes "for an atheist" ([9], p. 66; [10], p. 155), but by "atheism" he means openness to otherness-absolute otherness which cannot be named so that it might mean the messianic as well as the monstrous ([1], p. 71). Derrida refers to "messianicity" rather than "messianism" in order to renunciate "a specific God (or Gods)—a renunciation which could almost to be said to serve as

\footnotetext{
With reference to Levinas's "hostage," ([31], p. 9); See also ([32], pp. 108-11).

According to Kearney, for Derrida impossibility becomes the condition of possibility. See ([1], pp. 96-98).

This moment is anticipated in ([37], pp. 61-67), where Derrida argues that the relation to absolute alterity is at the core of religion. Transcendence is absolute transcendence for Derrida. See also ([9], p. 71).

31 For a short summary of Kearney's account of Derrida, see also ([8], pp. 169-71).

32 Kearney [8], with reference to [38]. See also ([1], p. 73).

33 Kearney ([7], p. 64). The famous formula "religion without religion" was proposed by Derrida and popularized by [39].
} 
condition of possibility of a God still to come, still to be named." 34 "In the heel of the hunt," Kearney concludes critically, "he prefers ghosts to gods" ([1], pp. 98-99).

When Kearney states that he "pass[es] rightly for a theist," he takes on Derrida's religion without religion [42]. For Kearney, the other is actual and acute, never abstract and absolute. Hence, what Kearney wants to overcome is the "all-inclusiveness" of hospitality, "summed up in the claim-tout ature est tout autre." ${ }^{\prime 3}$ Since it is rooted in absolute alterity, "faith serves here as a purely transcendental move, a 'formal structure of promise' that does not call for realization...in the world of particular beliefs" ([7], p. 64). This formalization of faith, which focuses on the 'that' of the other rather than the "what' of the other, "may lead," Kearney warns, "less to praxis than to paralysis," 36 because the discernment between the other who should and the other who should not be welcomed is relegated to "calculating legislation invariably compromised by injustice"([3], p. 70). In order to practice hospitality, Kearney proposes, the openness to otherness characteristic of trust is not enough: "one must also be careful to discern, in some provisional fashion at least, between different kinds of otherness." ${ }^{\prime 37}$ Kearney criticizes and counters Derrida's explosion of ethics through eschatology. A diacritical hermeneutic is vital for an ethics which works through the distinction of the other who should and the other who should not be welcomed, ${ }^{38}$ because it "keeps in contact with the other. Indeed, I would argue that it is because of this ethical contact, always striving to make the other that little less alien, that we can tender (however provisionally) different interpretations of this or that other. And it is ultimately, I believe, in tune with such discernments that we may offer some tentative judgments about what kinds of others we have before us" ([3], p. 81; [7], p. 45).

Kearney develops his diacritical hermeneutic throughout the trilogy "Philosophy at the Limit," but he offers his most in-depth and in-detail description of discernment in Anatheism ([7], pp. 40-56). Here, Kearney names the "aspects of a single hermeneutic arc" which allow him to discern between benign and malign others ([7], p. 40). Either inadvertently or advertently, he argues, discernment happens ([48], pp. 149-62). It runs through all the aspects of the hermeneutic arc ([7], pp. 40-56). "Hermeneutics goes all the way down" ([7], p. 46). Hence, Kearney reflects on the "carnal" response to the other through which the distinction between monsters and messiahs can be drawn from case to case. ${ }^{39}$ Accordingly, for Kearney, hospitality to the other is always already conditioned: unconditional hospitality is a possibility - but it is a possibility for the infinite rather than the finite other. It is "divine" ([7], p. 48). For all others, there is a "moment of choice. (Even if that choice is to have no choice-to remain in indecision—it is still a choice: namely, the choice not to choose.)" ([7], p. 44). In the encounter with the otherness of the other, hermeneutical mediation is required: "we export ourselves into strangers and import strangers into ourselves. And, in daring to translate across borders, we encounter the limits of translatability" ([7], p. 179). If the other is infinite rather than finite, "we might say that it charts a winding path between the apophatic and cataphatic approaches to God" ([1], p. 8).

To summarize, Derrida argues for the other as absolute other. Since one cannot say anything about her, one cannot distinguish between the other who should be welcomed and the other who

34 Kearney [1], with reference to [40]. In his reflections on religion, Immanuel Kant is one of Derrida's indispensable interlocutors. It is noteworthy that Derrida's distinction between messianicity and messianism comes close to what Kant writes in The Conflict of the Faculties, where he distinguishes between "pure" faith, not tainted by ecclesiastical rules, and impure faith, tainted by ecclesiastical rules. For Kant-and for Derrida-the impure "ecclesiastical faith" is the "vehicle" of the "pure" non-ecclesiastical faith [41].

35

([1], p. 72). The formula appears in ([37], pp. 78-80). See also [43]: "Tout autre est tout autre-that is the postmodern contribution to the medieval list of transcendentals."

36 ([3], pp. 107-8). Elsewhere, however, Kearney writes that "Derrida's identification of a contradictory logic at the heart of the concept of cosmopolitanism is not staged in order to paralyse political action, but, on the contrary, in order to enable it." See [44]. Since the contradictory logic of cosmopolitanism also applies to Derrida's account of hospitality, it is not clear how the contradictory logic can have paralyzing consequences, on the one hand, and practical consequences, on the other hand.

37 ([3], p. 77). See also ([45], p. 51). See also the summary by ([46], pp. 173-84).

38 ([3], pp. 79-80). Here, Kearney takes up Paul Ricoeur's critique of Levinas in [47]. For Kearney, there "is no way for the other to find its way into the hermeneutic circle without entering the web of figuration" ([3], p. 80).

39 See [49]. See also, again ([48], p. 160). 
should not be welcomed. On the contrary, for hospitality to be hospitality, trust has to be unconditional rather than conditional, open to any other as the absolute other. For Derrida, the driver's decision about whether she should or she should not take the other into her taxi is dangerous rather than delicate: since she cannot make any claims about the other without confining or controlling her, she has to drive any other as the absolute other. Trust is indeed blind ([35], p. 70). The other is more a matter of eschatology than a matter of ethics-potential rather than present. For Kearney, however, the distinction between the other who should be driven and the other who should not be driven in the taxi is delicate and decisive for ethics. Without this distinction, one knows neither what the present other might be, nor what the potential other might bring.

\section{Transcendence and Trust in the Taxi}

Claudia Welz offers a philosophical-phenomenological account of trust. She analyzes trust as "opening (Öffnung) or openness (Offenheit) for the other," where both are experienced as "self-transcendence." 40 The ek-stasis of the self, then, on which Kearney agrees with Derrida and Derrida agrees with Kearney, is essential to her account of trust. Trust is the opposite of control so that it could be conceptualized as a relation to the other which is characterized by openness to the other's otherness. Here, all agree. ${ }^{41}$ What is at stake in the disagreement is how open one could and should be to the other in order to trust her. How could and how should the other be approached?

For Derrida, the other is so other that one cannot say anything about her. However, if one cannot say anything about her, one cannot relate to her-neither with, nor without, trust. In as much as the concept of the absolute conveys the non-relational rather than the relational, one cannot relate to the absolute other. Derrida's other remains outside of one's orbit, continuously to come. Absolute alterity, then, is about a conceptual relationality rather than a concrete relation. ${ }^{42}$ Theologically, Derrida reduces what has been said about God throughout the history of religion(s) to a gesture, a deictic designation of the 'that' rather than the 'what' of alterity ([6], p. 317). In traditional theological terminology, he opts for fides qua (the believing) against fides quae (the beliefs). On his account, there is no way to register or to recognize the otherness of the other as a concrete rather than a conceptual transcendence. ${ }^{43}$ Eschatology is empty. Described differently, Derrida claims that trust entails that one cannot capture the other. However, in order to trust the other, one has to capture her to some extent. What is crucial for trust, then, is not that one cannot capture her, but that one cannot capture her completely. The difference is subtle but significant. ${ }^{44}$ Here, Kearney's diacritical critique of deconstruction is instructive for theology and philosophy. Kearney is correct to insist that the other is encountered concretely and carnally. However, when he concludes from his critique of absolute alterity that one can distinguish between the other who should and the other who should not be welcomed before one encounters the other, his critique becomes problematic.

In contrast to Derrida, Kearney argues that the leap of faith toward the other could not, and should not, be blind ([1], p. 76; [7], p. 45). Although one ought to remain open to the other, one can judge which others do and which others do not deserve one's trust. However, how does one

40 [50]. See also ([50], pp. 91-93). For a detailed discussion of openness, see also ([51], pp. 45-64).

41 Kearney agrees with Derrida (and Derrida agrees with Kearney) that trust is crucial for the encounter with the other. Both of them use trust for faith and faith for trust, but for Derrida trust is blind and for Kearney trust is anything but blind. See ([1], p. 76) However, neither of them offers an in-depth and in-detail account of trust.

42 In [52]. Derrida takes his animal as absolute alterity ([52], p. 11). However, here he argues that his cat-“ "this irreplaceable living being" —is acute rather than abstract, but nonetheless other ([52], p. 9)—emphasis in the original). Derrida's account for the "unsubstitutional singularity" [52] of his cat arguably allows for a Derridean critique of absolute alterity.

43 In [53]. Derrida argues, against Levinas, that alterity cannot be absolute because any attempt to think alterity contaminates its absoluteness. In [54], however, absolute alterity is not subjected to such a critique. See also ([55], pp. 121-23).

44 See also ([1], p. 98): “Derrida sees in the play of impossible-possible a structure of 'experience in general.' ... By contrast, I would want to claim it marks a specifically religious experience of God. And I would suggest that this is a difference not only of language games but also of 'reference'." See also Kearney's engagement with Derrida in "Deconstruction, God, and the Possible," in ([36], pp. 297-308). 
know whether the judgement one has made is appropriate or inappropriate? Welz probes trust through a phenomenology of "judgment (Urteil)" and "misjudgment (Fehlurteil)" ([50], pp. 33-68). She explains that a person exposes the judgment she has made as either correct or incorrect through a judgment of the judgment she has made: the judgment of the judgment enables the "self-relocation" of the person with regard to her judgment ([50], p. 38). The judgement about trust, however, is decidedly different. When the person judges trust, her judgment is not a post-judgment but a pre-judgment: a "prejudice (Vor-Urteil)" ([50], p. 39). With the reference to pre-judgment, Welz arguably adopts Hans-Georg Gadamer's "rehabilitation" of the "prejudice" in the process of interpretation. ${ }^{45}$ Gadamer's hermeneutics pinpoints the productive power of prejudices: a prejudice is needed in order to approach the object of interpretation (whatever it may be), because it allows the subject of interpretation to form and inform a perspective. Although the prejudice might be changed in the process of interpretation, interpretation is impossible without prejudices. Hence, in order to encounter the other, one has to assume that she will not exploit one's openness. This assumption-the prejudice of trust-is what enables the interaction with the other in which one can find out whether the other is trustworthy or non-trustworthy $([50]$, p. 39). The prejudice is what makes trust a wager in the first place, because the in/correctness of the assumption will be revealed only after one opens oneself to the other. Since the non/trustworthiness of the other cannot be judged prior to the relation to the other, one has to be prejudiced to trust her in order to judge her trustworthiness or her non-trustworthiness. This prejudice is essential to the ek-statis of the self.

Accordingly, Welz argues that trust is the point of departure for a relation to the other ([50], pp. 60-67). Demanding discernment between the trustworthy and the non-trustworthy other, then, Kearney's diacritical hermeneutics runs the risk of stopping the relation to the other before it started. For Kearney, one's trust requires that the other is trustworthy rather than non-trustworthy. However, Welz insists that one cannot know whether she is or is not trustworthy unless one trusts her. When one calls for discernment between the trustworthy and the non-trustworthy other before one has opened oneself up to the other, trust has become suspicious: trust is distrusted and distrust is trusted ([50], p. 57). The theological consequences are apparent when Kearney argues that he "cannot accept" that God could be a monster and a monster could be God: "God, for me, is always good-both actually and potentially" ([45], p. 51) Here, he claims to know who or what God is. ${ }^{46}$ But the condition of his claim to knowledge of God is the leap of faith. Only after the leap can one know God. ${ }^{47}$ On Kearney's account, however, one has to know who or what God is (and who or what God is not) in order to decide who or what one encounters in the other-messiah or monster. Hence, deliberately or undeliberately, Kearney curtails the ek-stasis of the self for which he called; thus, controlling God's transformative transcendence.

With his call for discernment between the other who should be trusted and the other who should not be trusted, Kearney inadvertently introduces two concepts of transcendence. These two concepts are at work in his critique of Derrida's account of any other as absolute other. When he argues that this account is "compromising God's unique transcendence," he assumes that the transcendence of the finite other differs from the transcendence of the infinite other ([1], p. 74). This difference is

45 See [56]. Welz does not refer to Gadamer; however, she, like Gadamer, develops the rehabilitation of prejudice in critical conversation with Immanuel Kant. See ([50], pp. 43-54).

46 Boeve points out that it is ultimately unclear in what Kearney's claim to knowledge is anchored. ([6], pp. 320-21). The critique is repeated in: $[57,58]$. Accordingly, Boeve argues that the hermeneutics of religion-diacritical or not diacritical一cannot but come back to its own particularity. However, Boeve's (re)turn to particularity ignores the critique or the self-critique of particularity so crucial to the diacritical (or indeed the deconstructive) hermeneutics. Kearney wants to portray uncertainty as advantageous rather than disadvantageous for faith—the advantage would be lost in the turn or re-turn to particularity proposed by Boeve. See also [59].

47 Joshua Mills-Knutsen ([60], p. 526) argues that Derrida's concept of hospitality “is more than one proposal among others on how judgments should be rendered. It is instead the very questioning of the right to Kearney's (even tentative) judgements." Considering trust, I would argue that the point is not whether judgments are allowed but when judgements are allowed-namely, not in advance. 
not a difference in degree. While the creator's transcendence cannot, the creature's transcendence can, be dangerous. Here, Kearney dismisses the fascinating functionalization of transcendence that supported the sacramentality of the other. For if the transcendence of God is 'compromised' by God's creatures, how can the transcendence of the finite other communicate the transcendence of the infinite other? Both the promise and the point of the functionalization of transcendence were to describe the transcendence of the infinite other in analogy to the transcendence of the finite other so that the experience of the other connects them. ${ }^{48}$ The compromise is the condition of the communication of transcendence. Without the functionalization of transcendence, then, the taxi remains a suspenseful but not a sacramental site.

Although Kearney's critique of absolute alterity is instructive, Derrida's critique of the conditioning of hospitality might be more crucial than Kearney contends. When Kearney asks whether by "releasing the 'desire of God' from any particular tradition of revelation ... does deconstruction not make it difficult for us to address the human need to identify divinity, to look for at least some sort of credentials before taking it in—or being taken in?" ([26], p. 75, my emphasis), he is correct to insist that one needs an actual, rather than an abstract, account of the other in order to relate to her. However, if this account is required 'before' taking in or being taken in by the other, the relation to the other is stopped before it started. Kearney's account of "truth as trust," where truth is interpreted as performative, rather than propositional so that trust makes truth, ${ }^{49}$ is curtailed and collapsed when one needs to know whether the other is or is not trustworthy prior to one's trust in her. Here, it is trust that depends on truth, rather than truth that depends on trust. Ethics has trumped eschatology.

However, one does not have to delve into Derrida's empty eschatology in order to insist that eschatology is important and instructive for ethics. Since one cannot decide whether the other is trustworthy or non-trustworthy prior to the relation to the other, the prejudice of trust is indispensable for any encounter with both finite and infinite others. Trust is always already appropriate. The trusting leap towards the other is blind in the sense that the disappointment of trust cannot be avoided without turning from trust to mistrust ([50], p. 57). Even after one's trust in the other has been disappointed, trust might be important. It is the only way to start or re-start a relation to the other, the finite as well as the infinite. Of course, hermeneutics goes all the way down; it is, as Kearney argues, carnal. However, Derrida provokes the hermeneut not to ask whether she can trust her pre-reflective carnal trust, but whether she can trust her pre-reflective carnal distrust. The carnal response to the other, through which one interprets whether the other is or is not trustworthy, is not infallible. Hence, in the encounter with another who appears non-trustworthy rather than trustworthy, one should cast doubt on the appearance. The other deserves the benefit of this doubt: "in order to ask there must first be a certain 'yes'," as Derrida announces. ${ }^{50}$ The other has to be approached in trust rather than distrust. Deconstruction insists on this prejudice of trust because there are no parameters which would allow for a decision about the non/trustworthiness of the other in advance ([9], p. 81). Driving a taxi takes trust, because the driver acquires knowledge about the other only while she is driving her. Whether the other is or is not trustworthy becomes clear only after she has been taken into the taxi.

To conclude, throughout his trilogy, "Philosophy at the Limit," Kearney functionalizes transcendence. The functionalization allows him sacramentally to see the transcendence of the finite other in the transcendence of the infinite other and the transcendence of the infinite other in the transcendence of the finite other. Where Kearney disagrees with Derrida (and Derrida with Kearney) is in the account of alterity. What is at stake in their disagreement is where the emphasis lies in

48 Incidentally, the analogical logic is already apparent in Friedrich D. E. Schleiermacher, who argued that the unlimited dependence which denotes the relation to the creator is analogically related to the limited dependence which denotes the relation to the creature. See [61].

49 See ([7], p. 44), where Kearney charts the contours of "truth as trust," albeit without a fully-fledged definition or discussion. See also ([7], pp. 203-4).

50 ([31], p. 12), with reference to Martin Heidegger's concept of Zusage. See also ([62]; [63], pp. 176-80), interprets Derrida's "yes" as a form of foundational trust. See also ([43], p. 97). 
the entanglement of ethics and eschatology: Derrida, unlike Kearney, stresses the significance of eschatology; Kearney, unlike Derrida, stresses the significance of ethics. If trust is taken as a point of departure to think through ethics and eschatology, however, Kearney can correct Derrida and Derrida can correct Kearney. Trust requires that the other is thought of relationally rather than non-relationally. And a relation to the other requires, pace Derrida, a hermeneutic which, like Kearney's diacritical hermeneutic, works beyond both the 'romantic' collapse of relationality into interiority and the 'radical' collapse of relationality into exteriority. But because one cannot discern whether the other is or is not trustworthy before one relates to her, the relation of trust requires a prejudice of trust. Both ethically and eschatologically, the prejudice means that one relinquishes control over the other. Derrida provokes the one who encounters the other to accept her vulnerability. Once one is in the relation with the other, the prejudice of trust might support a practice of trust and the practice of trust might support the prejudice of trust. Here, after the prejudice of trust, Kearney's diacritical hermeneutics can be developed both ethically and eschatologically. However, in order to enter such a relation, one needs to be prejudiced to trust.

Trust, then, is the way to relate to the transcendence of the other. If transcendence is interpreted functionally-by what it does-both the finite and the infinite other are connected through transcendence because, experientially, both are transcending: escaping one's evaluations, exceeding one's expectations. The experience of the transcendence of the other requires that one makes oneself vulnerable to the other. The driver knows whether she should or should not be driving her passenger only after the passenger-be it a messiah or a monster-has entered the taxi. Taxi rides, then, are indeed about transcendence. And transcendence takes trust.

Conflicts of Interest: The author declares no conflict of interest.

\section{References}

1. Richard Kearney. The God Who May Be: A Hermeneutics of Religion. Bloomington: Indiana University Press, 2001.

2. Richard Kearney. On Stories. London: Routledge, 2002.

3. Richard Kearney. Strangers, Gods and Monsters: Interpreting Otherness. London: Routledge, 2003.

4. Blaise Pascal. Pensées: With an Introduction by Thomas S. Eliot. Translated by William F. Trotter. New York: Dutton, 1958.

5. Brian Trenor. "The Anatheistic Wager: Faith after faith." Religion and the Arts 14 (2010): 546-59. [CrossRef]

6. Lieven Boeve. "God, Particularity and Hermeneutics: A Critical-Constructive Theological Dialogue with Richard Kearney on Continental Philosophy's Turn (in)to Religion." Ephimerides Theologicae Lovanienses 81 (2005): 305-33. [CrossRef]

7. Richard Kearney. Anatheism: Returning to God after God. New York: Columbia University Press, 2010.

8. Richard Kearney. "Returning to God after God: Levinas, Derrida, Ricoeur." Research in Phenomenology 39 (2009): 167-83. [CrossRef]

9. Christina M. Gschwandtner. Postmodern Apologetics? Arguments for God in Contemporary Philosophy. New York: Fordham University Press, 2013.

10. Jacques Derrida. Circumfessions. Translated by Geoffrey Bennington. Chicago: University of Chicago Press, 1993.

11. William Desmond. "Maybe, Maybe Not: Richard Kearney and God." The Irish Theological Quarterly 68 (2003): 99-118. [CrossRef]

12. Jeffrey Bloechl. “Christianity and Possibility: On Kearney's The God Who May Be.” Metaphilosophy 36 (2005): 730-40. [CrossRef]

13. Patrick Masterson. "Richard Kearney's Hermeneutics of Otherness." Philosophy and Social Criticism 43 (2008): 247-65. [CrossRef]

14. Mark Dooley. "A Master of the Middle Way: Richard Kearney on God, Evil, and Aliens." Religion and the Arts 7 (2003): 329-39. [CrossRef]

15. Justin Sands. "Passing through Customs: Merold Westphal, Richard Kearney and the Methodological Boundaries between Philosophy and Theology." Religions 7 (2016): article 83. [CrossRef] 
16. Jean Greisch. "The 'Maker Mind' and its Shade: Richard Kearney's Hermeneutics of the Possible God." Research in Phenomenology 34 (2004): 246-54. [CrossRef]

17. John Rundell. "Imaginings, Narratives and Otherness: On the Critical Hermeneutics of Richard Kearney." Thesis Eleven 73 (2003): 97-111. [CrossRef]

18. Grace Davie. The Sociology of Religion. London: Sage, 2007, pp. 19-20.

19. Patrick Masterson. "Richard Kearney's Hermeneutics of Otherness." Philosophy E Social Criticism 34 (2008): 247-65. [CrossRef]

20. Karl Barth. The Epistle to the Romans. Translated by Edwyn C. Hoskyns. Oxford: Oxford University Press, 1991, p. 30.

21. Ingolf U. Dalferth. "The Idea of Transcendence." In The Axial Age and Its Consequences. Edited by Robert N. Bellah and Hans Joas. Harvard: Harvard University Press, 2012, pp. 146-88.

22. Richard Kearney. "Transcendent Humanism in a Secular Age: Dialogue with Charles Taylor." In Reimagining the Sacred: Richard Kearney Debates God. Edited by Richard Kearney and Jens Zimmermann. New York: Columbia University Press, 2016, pp. 76-92.

23. Rudolf Otto. The Idea of the Holy: An Inquiry into the Non-Rational in the Idea of the Divine and its Relation to the Rational. Translated by John W. Harvey. London: Oxford University Press, 1924.

24. Paul Ricouer. The Rule of Metaphor: The Creation of Meaning in Language. Translated by Robert Czerny, Kathleen McLaughlin and John Costello. London: Routledge, 2003.

25. Richard Kearney. Paul Ricoeur: The Owl of Minerva. Farnham: Ashgate, 2004.

26. Richard Kearney. "The God Who May Be: A Phenomenological Study." Modern Theology 18 (2002): 75-85.

27. Stanislas Breton. "Kearney's The God Who May Be." Research in Phenomenology 34 (2004): 255-65. [CrossRef]

28. John P. Manoussakis. “From Exodus to Eschaton: On the God Who May Be." Modern Theology 18 (2002): 95-107.

29. Richard Kearney. "Re-imagining God." In Transcendence and Beyond: A Postmodern Inquiry. Edited by John D. Caputo and Michael J. Scanlon. Bloomington: Indiana University Press, 2007, pp. 53-54.

30. John Caputo. "Richard Kearney's Enthusiasm: A Philosophical Exploration on The God Who May Be." Modern Theology 18 (2002): 87-94.

31. Jacques Derrida. "Hostipitality." Translated by Barry Stocker with Forbes Morlock. Angelaki: Journal of the Theoretical Humanities 5 (2000): 3-18. [CrossRef]

32. Jacques Derrida. Of Hospitality: Anne Dufourmantelle invites Jacques Derrida to Respond. Stanford: Stanford University Press, 2000, p. 21.

33. Émile Benveniste. Indo-European Language and Society. Coral Gables: University of Miami Press, 1973.

34. Gerasimos Kakoloris. "Derrida and the Ethics of Hospitality." In The Ethics of Subjectivity: Perspectives since the Dawn of Modernity. Edited by Elvis Imafidon. New York: Palgrave Macmillan, 2015, pp. 144-56.

35. Jacques Derrida. "Faith and Knowledge." In Acts of Religion. Edited by Gil Anidjar. Translated by Samuel Weber. London: Routledge, 2010, pp. 40-101.

36. Jacques Derrida, John D. Caputo, Kevin Hart, and Yvonne Sherwood. “Epoché and Faith: An Interview with Jacques Derrida." In Derrida and Religion: Other Testaments. Edited by Kevin Hart and Yvonne Sherwood. London: Routledge, 2005, pp. 27-50.

37. Jacques Derrida. The Gift of Death. Translated by David Willis. Chicago: University of Chicago Press, 1992, pp. 57-58, 61-67.

38. Jacques Derrida. "Sauf le nom (Post-Scriptum)." In On the Name. Edited by Thomas Dutoit. Translated by David Wood, John P. Leavey Jr. and Ian McLeod. Stanford: Stanford University Press, 1995, pp. 35-88.

39. John Caputo. The Prayers and Tears of Jacques Derrida. Bloomington: Indiana University Press, 1997.

40. Jacques Derrida. Specters of Marx: The State of the Debt, the Work of Mourning and the New International. Translated by Peggy Kamuf. London: Routledge, 1994, pp. 167-70.

41. Immanuel Kant. The Conflict of the Faculties (Der Streit der Fakultäten). Translated by Mary J. Gregor. Lincoln: University of Nebraska Press, 1979, pp. 61-63.

42. Richard Kearney, and Liam Kavanagh. "Facing God: An Interview with Richard Kearney." Journal of Philosophy and Scripture 1 (2004): 2-10.

43. John Caputo. "Hospitality and the Trouble with God." In Phenomenologies of the Stranger: Hospitality and Hostility. Edited by Richard Keareny and Kascha Semonovich. New York: Fordham University Press, 2011, pp. 83-97. 
44. Richard Kearney, and Simon Critchley. "Preface." In Cosmopolitanism and Forgiveness. London: Routledge, 2001, pp. vii-xii.

45. Richard Kearney. "Beyond the Impossible: Dialogue with Catherine Keller." In Reimagining the Sacred. New York: Columbia University Press, 2015, pp. 46-75.

46. Richard Kearney. "Hospitality: possible or impossible? " Hospitality and Society 5 (2015): 173-84. [CrossRef]

47. Paul Ricœur. Oneself as Another. Translated by K. Blamey. Chicago: The University of Chicago Press, 1992, pp. $188-89$.

48. Theo L. Hettema. "When the thin small voice whispers: Richard Kearney's Anatheism and the postsecular discernment of spirits." International Journal of Philosophy and Theology 76 (2015): 149-62. [CrossRef]

49. Richard Kearney. "What is Carnal Hermeneutics?" New Literary History 46 (2015): 99-124. [CrossRef]

50. Claudia Welz. Vertrauen und Versuchung. Tübingen: Mohr Siebeck, 2010, p. 5.

51. Claudia Welz. "Trust as Basic Openness and Self-Transcendence." In Trust, Sociality, Selfhood. Edited by Claudia Welz and Arne Grøn. Tübingen: Mohr Siebeck, 2010, pp. 45-64.

52. Jacques Derrida, and David Wills. The Animal That Therefore I Am. Edited by Marie-Louise Mallet. Translated by David Wills. New York: Fordham University Press, 2008.

53. Jacques Derrida. "Violence and Metaphysics: An Essay on the Thought of Emmanuel Levinas." In Writing and Difference. Translated by Alan Bass. London: Routledge, 2001, pp. 97-192.

54. Jacques Derrida. Adieu: To Emmanuel Levinas. Translated by Pascale-Anne Brault and Michael Naas. Stanford: Stanford University Press, 1997.

55. Peter E. Gordon. "Habermas, Derrida, and the Question of Religion." In The Trace of God: Derrida and Religion. Edited by Edward Baring and Peter E. Gordon. New York: Fordham University Press, 2015, pp. 110-31.

56. Hans-Georg Gadamer. Truth and Method. Translation revised by Joel Weinsheimer and Donald G. Marshall. London: Sheed and Ward Limited, 1989, pp. 265-306.

57. Lieven Boeve. "The Particularity of the Hermeneutics of God: A response to Richard Kearney's God-who-maybe." In Faith in the Enlightenment? The Critique of the Enlightenment Revisited. Edited by Lieven Boeve, Joeri Schrijvers, Wessel Stoker and Hendrik M. Vroom. Amsterdam: Rodopoi, 2006, pp. 327-39.

58. Lieven Boeve. "Richard Kearney's Messianism: Between the Narrative Theology of Hermeneutics and the Negative Theology of Deconstructionism." In Between Philosophy and Theology: Contemporary Interpretations of Christianity. Edited by Lieven Boeve and Christoph Brabant. Farnham: Ashgate, 2010, pp. 7-18.

59. Brian Trenor. "The Anatheistic Wager." Faith after Faith 14 (2010): 554-55.

60. Joshua Mills-Knutsen. "Becoming Stranger: Defending the Ethics of Absolute Hospitality in a Potentially Hostile World." Religion and the Arts 14 (2010): 522-33. [CrossRef]

61. Friedrich Schleiermacher. The Christian Faith. Edited by Hugh R. Mackintosh and James S. Stewart. Edinburgh: T\&T Clark, 1928, pp. 14-16.

62. Jacques Derrida. Of Spirit: Heidegger and the Question. Translated by Geoffrey Bennington, and Rachel Bowlby. Chicago: Chicago University Press, 1987, pp. 129-36.

63. Emil Angehrn. "Grundvertrauen zwischen Metaphysik und Hermeneutik. Vom Seinsvertrauen zum Vertrauen in den Menschen." In Grundvertrauen: Hermeneutik eines Grenzphänomens. Edited by Ingolf U. Dalferth and Simon Peng-Keller. Leipzig: EVA, 2012, pp. 161-85.

(C) 2017 by the author. Licensee MDPI, Basel, Switzerland. This article is an open access article distributed under the terms and conditions of the Creative Commons Attribution (CC BY) license (http:/ / creativecommons.org/licenses/by/4.0/). 